\title{
METHODICAL INSTRUMENTS OF STATE TAX REGULATION OF DEVELOPMENT OF SMALL AND MEDIUM BUSINESSES IN RUSSIA
}

\section{Madina Alikaeva}

Kabardino-Balkarian State University named after H.M. Berbekov, Nalchik, Russia

\section{Madina Ksanayeva}

Kabardino-Balkarian State University named after H.M. Berbekov, Nalchik, Russia

\section{Lyudmila Prigoda}

Maikop State University of Technology, Maikop, Russia

CMESTE

JEL Category: H71

\begin{abstract}
The article considers the features of the sector of small and medium business as an object of state tax regulation. The functions of state tax regulation are implemented not only in the level of mobilization of taxes and ensuring the country's expenses. Its effectiveness is also manifested in the impact on the economic situation, ensuring the country's GDP growth, profitability, and business development, especially in small forms, and the growth of the welfare of the population. A study of the effectiveness of state tax regulation of the development of small and medium-sized enterprises necessitates the consideration of the identification features of this sector as an object of regulation, justification why it is isolated from the totality of regulatory objects.
\end{abstract}

Keywords: small and medium business, tax regulation, state regulation, taxation.

\section{INTRODUCTION}

Small and medium-sized enterprises (SMEs) play an important role in ensuring the sustainable development of the Russian economy. The subjects of this sector are dynamic and highly

Address of the corresponding author: Madina Alikaeva 害- Alika123@rambler.ru adaptable, allowing them to respond quickly to market volatility, changes in consumer tastes and preferences, and to address the employment problem of the working population, especially during periods of shrinking large industries.

The current situation in this sector of the Russian economy in 2014-2019, as well as the need to ensure its dynamic growth, requires a significant intensification of government policy in support of 
SMEs and elimination of factors that hinder their development and contribute to the shadowing of their activities. Taxation of SMEs remains the most problematic area in the domestic system of state regulation and support

\section{RESEARCH ISSUE}

The term "small and medium-sized business entities" was introduced by Federal Law No. FZ-

Table 1 - Criteria for classifying economic entities as micro, small and medium in Russia (Duma, 2017)

\begin{tabular}{|l|r|r|r|}
\hline \multicolumn{1}{|c|}{ Indicator / Subject group } & \multicolumn{1}{c|}{ Micro- } & \multicolumn{1}{c|}{ Small } & \multicolumn{2}{c|}{ Medium } \\
\hline Number of employees, persons & under 15 & between 15 and 100 & between 101 to 250 \\
\hline Volume of annual revenue, million rubles & 120 & 800 & 2000 \\
\hline $\begin{array}{l}\text { Share of other legal entities in the charter } \\
\text { capital of the organization, \% }\end{array}$ & 25 & 25 & 25 \\
\hline
\end{tabular}

In our opinion, the criteria listed in Table 1 do not meet the current tasks of state regulation of the development of this sector of the economy and need further improvement. Thus, the abolition of differentiation of the limit-number of employees of small and medium-sized enterprises by types of activity has led to an excessive simplification of this criterion, which is not compensated by the relative ease of its use. For labor-intensive industries, this parameter will allow for a reasonable and correct classification of enterprises by size, since the number of employees largely determines the production capacity of enterprises belonging to them. However, for knowledge-intensive, innovative industries, this category may include enterprises that occupy an almost monopolistic position on local regional markets and, therefore, should not be the object of state protection (Ksanaeva, 2013, p. 27).

The presence of an objective need to preserve and develop the potential of the entrepreneurial sector makes it necessary to create the most favorable environment for entrepreneurship. Support of entrepreneurial activity by the state functionally assumes the use of a whole complex of measures, both stimulating and regulating influence in the sphere of budget and tax, monetary, legal, and social policy (Bykova, 2018).

\footnotetext{
1 Excluding business entities that meet the conditions specified in subparagraphs "b" - "e" of paragraphs 1.1. of Article 4 of the Federal Law-209 of 24.07.2007.

2 The Government of the Russian Federation has the right to set a limit on the average number of employees
}

209 of 24 July 2007 "On the development of small and medium-sized business in the Russian Federation" (hereinafter referred to as the Federal Law-209) and includes both legal entities and individual entrepreneurs who meet the established criteria for qualifying as micro, small and mediumsized entities ${ }^{1}$ (Table 1) (Duma, 2017).
The state regulation of enterprise activity represents the uniform mechanism in which elements are both state and enterprise structures, promoting optimum functioning of the market economy (Iziev \& Izieva, 2018). At the end of the twentieth century, the prevailing view was that state interference in the national economy should be limited. However, the Russian economic practice of the last twenty years with its inherent crises of financial, monetary and banking systems, positive dynamics of unemployment growth, the decline in social production convincingly testifies to the necessity to strengthen the role of the state in regulating the national economy (Bykova, 2018, p. 15).

In the conditions of modern market economy the state regulation of entrepreneurial activity, especially in small forms, is one of the main ways of technical and product development of social reproduction, as well as the most optimal way of transformation of the national economy from raw materials to processing (Alikaeva \& Ksanaeva, 2013, p. 22).

\section{PURPOSE OF THE STUDY}

The purpose of the study is to study the characteristics of SMEs as an object of tax regulation.

for the previous calendar year in excess of the value set by subparagraph "b" of paragraph 2 of the Federal Law209 of 24.07.2007. 


\section{RESEARCH METHODS}

The study used generally accepted methods of cognition - comparative analysis, logical generalizations, tools of statistical and financial analysis.

\section{PROBLEM ANALYSIS}

The purpose of state regulation of SMEs is to create conditions for the stable functioning of the business environment, i.e. the task of the state to create optimal conditions for the functioning of all types of entrepreneurship (Solovyova, 2012, p. 19). Entrepreneurial activity functions under the influence of the external environment, being an integral element of the economic system in which it exists, develops, and interacts with other subsystems, including the state (fig. 1) (Bykova, 2018).

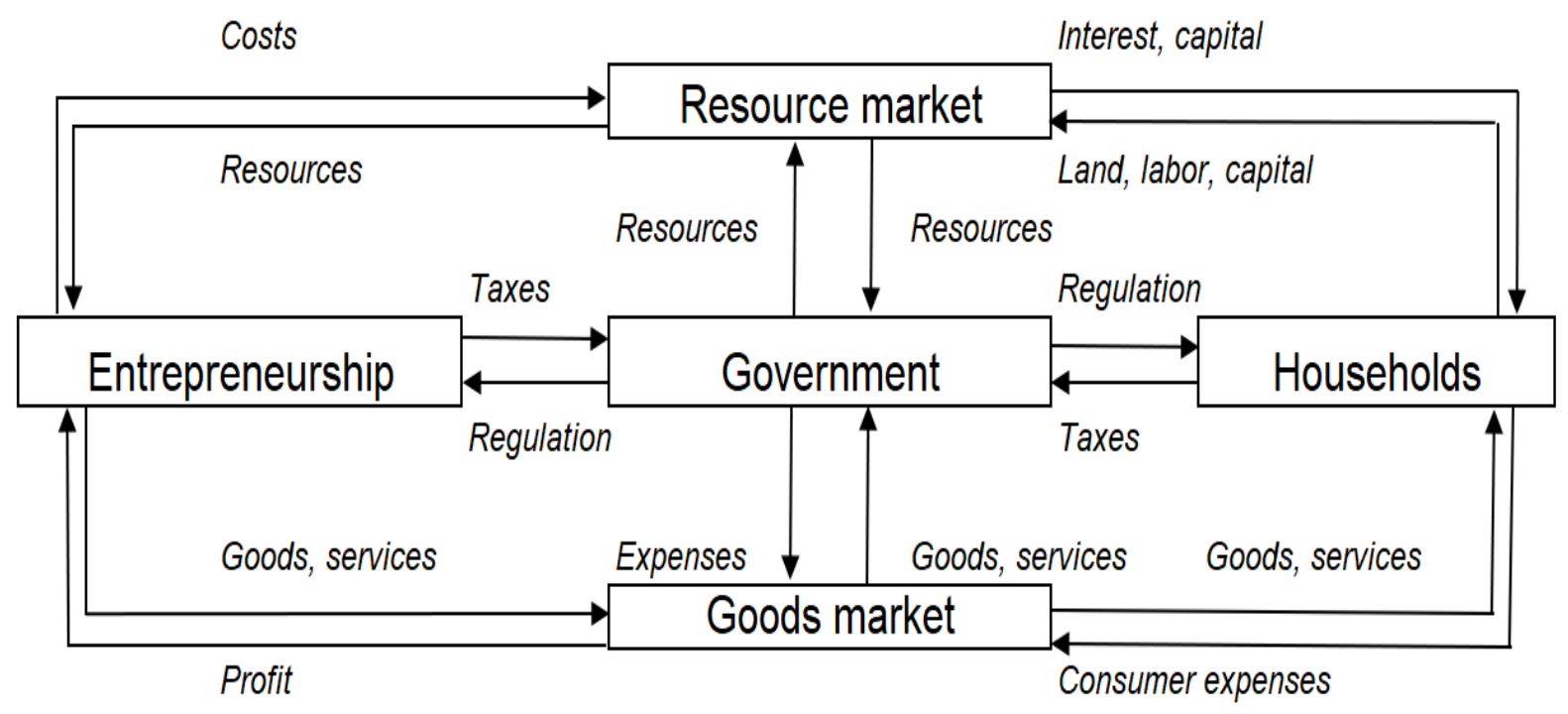

Figure 1 - Interrelation of business and state in the system of economic relations

Source: (Bykova, 2018, p. 30).
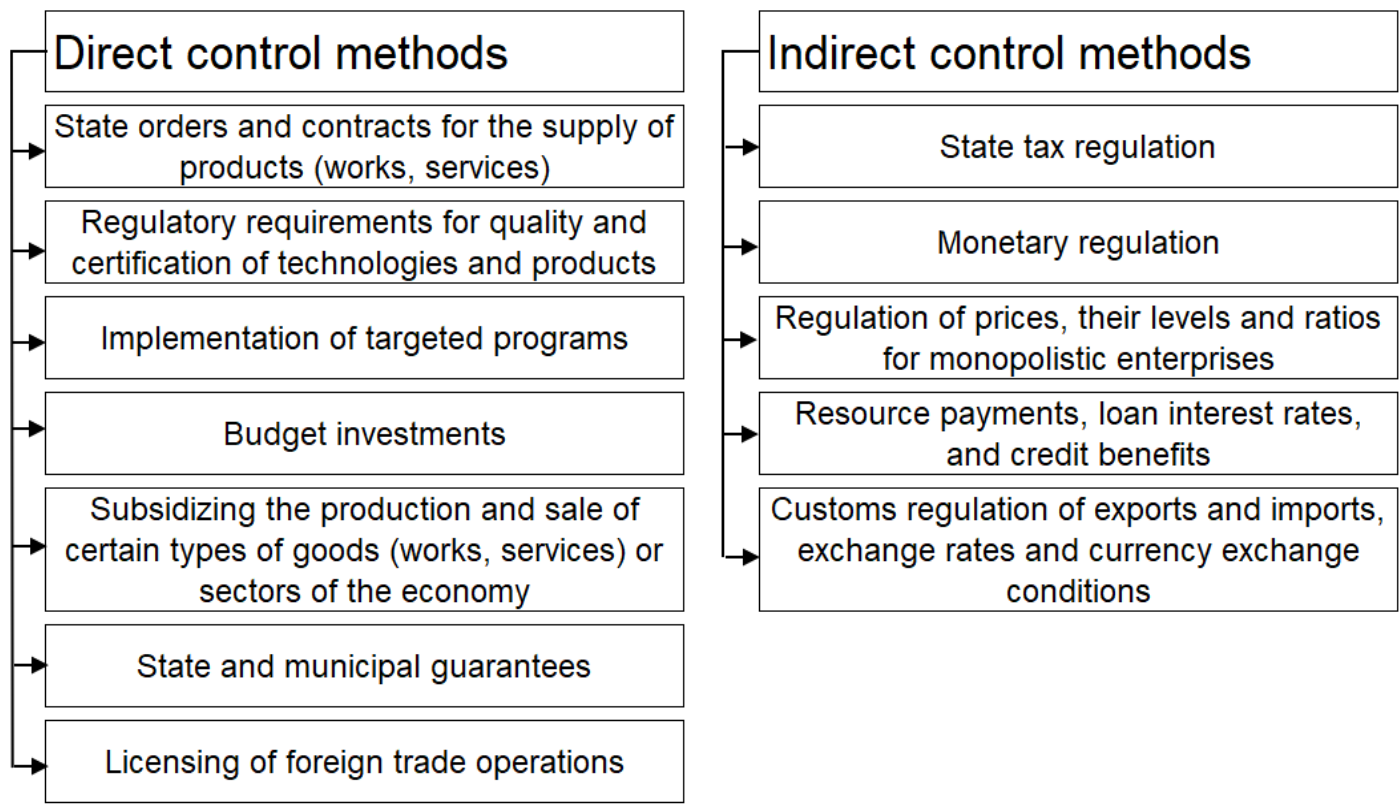

Figure 2 - Methods of state regulation of business activity.

Source: Developed by the authors

The main directions of state regulation of the development of this sector in Russia are determined by the goal set out in the strategy for the socio-economic development of the country - 
to ensure sustainable economic development, which is achieved through a system of state regulation.

The definition of state regulation includes the process of purposeful influence of the state on social processes using various means and methods of the regulation (Bykova, 2018, p. 32).

The state influences the system of SME development using direct and indirect methods of the regulation (Figure 2 ).

The state, through its institutions, controls the development activities of SME subjects by applying the methods of direct and indirect influence shown in Figure 2. Their use should not exacerbate crisis phenomena in the economy and destroy the market basis.

In accordance with the budgetary structure of the Russian Federation in the system of state regulation of SME development three levels of management are distinguished: federal level, regional and municipal (Duma, 1998). At the federal level of state power, activities are carried out to regulate and support SMEs in the following directions (Iskenderova, 2018):

- determination of priority directions of rendering state support to SMEs.

- formation of unified principles of organization of state regulation and support of SMEs.

- development of the regulatory and legal framework for the development of the entrepreneurial activity.

- determination of sources of financing and development of principles for the distribution of budget funds among the subjects of the Russian Federation.

- coordination of activities of regional and municipal structures of state executive power.

The tasks of state regulation of SMEs at the regional level are (Iskenderova, 2018) (Malyshev, Belyaev, \& Kashurnikova, 2018):

- creation of equal conditions for the participation of SME subjects in state support programs.

- creation of interdepartmental commissions at the regional administration to eliminate administrative barriers to the development of this sector.
- organization of interaction of small and medium enterprises with large industrial structures.

- development of a mechanism to involve SMEs in the execution of regional and municipal orders on a competitive basis.

- $\quad$ production and technical support to SMEs.

- organization of training, retraining, and professional development of personnel for small enterprises.

- $\quad$ support of foreign economic activity of SME subjects, including assistance in the development of their trade, scientific and technical, production, and information relations with foreign partners.

The tasks of the municipal level of state regulation are causally related to the regional level and do not contradict the policy of state regulation at the federal level. Thus, all levels of government are interconnected and interdependent, which requires a comprehensive approach to justifying and selecting measures of state support for SMEs and assessing their effectiveness (Malyshev, Belyaev, \& Kashurnikova, 2018).

The development by government authorities of effective mechanisms for supporting small and medium-sized enterprises is an essential stage in improving government economic policy. Therefore, it is necessary to pay special attention to the tax regulation of this sector and to consider methodological tools of state management of SME development.

State tax regulation is the performance of purposeful activities on the part of both state authorities and local self-government bodies regarding the establishment of tax preferences and other measures of a tax nature in the provisions of the legislation on taxes and collection of tax preferences, which improve not only the property but also the economic situation of certain categories of taxpayers (Kostromina, 2018).

The Constitution of the Russian Federation (Duma, Part One of the Civil Code of the Russian Federation from 30.11.1994 N 51-FZ. Adopted by the State Duma on 21.10.1994. (in effect, ed.), 1994, p. Art. 71) establishes a decisive role in the legal regulation of taxation for the federal center. At present, according to the provisions of the Tax Code of the Russian Federation, the following 
federal, regional, and local taxes are in force (Table 2) (Duma, 1998).

The norms of tax income distribution by levels of the budget system shown in Table 2 are reviewed annually and are relevant for the current financial year. For taxes paid during the transition to special taxation regimes, $100 \%$ of tax revenues are credited to the regional budget, excluding the production sharing agreement (Duma, 1998) (Duma, 2000) (Zakon, 2018) (Minfin, 2019).

Table 2 - System of federal, regional, and local taxes of the Russian Federation

\begin{tabular}{|c|c|c|c|c|c|c|}
\hline \multirow{2}{*}{ Group } & \multirow{2}{*}{\multicolumn{3}{|c|}{ Name of tax }} & \multicolumn{3}{|c|}{ Distribution of tax income } \\
\hline & & & & federal & regional & local \\
\hline \multirow[t]{11}{*}{ Federal taxes } & \multicolumn{3}{|c|}{ Value Added Tax } & $100 \%$ & - & - \\
\hline & \multirow{2}{*}{ Excise taxes } & \multicolumn{2}{|c|}{ On fuels and lubricants } & $12 \%$ & $88 \%$ & - \\
\hline & & \multicolumn{2}{|c|}{ For alcohol products } & $50 \%$ & $50 \%$ & - \\
\hline & \multicolumn{3}{|c|}{ Personal income tax } & - & $85 \%$ & $15 \%$ \\
\hline & \multicolumn{3}{|l|}{ Income tax } & $3 \%$ & $17 \%$ & - \\
\hline & \multicolumn{3}{|c|}{ Mineral extraction tax } & $100 \%$ & - & - \\
\hline & \multicolumn{3}{|l|}{ Water Tax } & $100 \%$ & - & - \\
\hline & \multirow{2}{*}{\multicolumn{2}{|c|}{ Fees for use of facilities }} & animal life & - & $100 \%$ & - \\
\hline & & & water resources & $20 \%$ & $80 \%$ & \\
\hline & \multicolumn{3}{|l|}{ State Duty } & - & $100 \%$ & - \\
\hline & \multicolumn{3}{|c|}{$\begin{array}{l}\text { Tax on additional income from hydrocarbon } \\
\text { production }\end{array}$} & $95 \%$ & $5 \%$ & - \\
\hline \multirow[t]{3}{*}{ Regional taxes } & \multicolumn{3}{|c|}{ Corporate property tax } & - & $100 \%$ & - \\
\hline & \multicolumn{3}{|c|}{ Tax on gambling business } & - & $100 \%$ & - \\
\hline & \multicolumn{3}{|c|}{ Transport tax } & - & $100 \%$ & - \\
\hline \multirow[t]{3}{*}{ Local taxes } & \multicolumn{3}{|c|}{ Land tax } & - & - & $100 \%$ \\
\hline & \multicolumn{3}{|c|}{ Property tax on individuals } & - & - & $100 \%$ \\
\hline & \multicolumn{3}{|l|}{ Trade fee } & - & - & $100 \%$ \\
\hline
\end{tabular}

Source: developed by the authors based on the analysis of the provisions of the Tax Code of the Russian Federation, Budgetary Code of the Russian Federation.

Since the 2000s, consolidated budgets of the constituent territories of the Russian Federation have accounted for about $40 \%$ of tax revenues of the budget system, but the share of regional and local taxes is low (less than $10 \%$ ), which means that regional authorities have a certain interest in the development of tax potential, remaining dependent on the federal center in the field of tax policy and interbudgetary relations (Alikaeva \& Ksanaeva, 2013). In 2020-2021, it is planned to gradually reduce the share of sub-federal budgets in the tax revenues of the Russian Federation, which requires the government authorities of the constituent territories of the Russian Federation to intensify their work on building up the tax base for regional and local taxes (Zakon, 2018) (Minfin, 2019).

Tax exemptions in the Russian Federation are established by the Tax Code of the Russian Federation. Additional exemptions from regional and local taxes can be established by regional legislation and regulatory legal acts of local governments of municipal entities respectively (Duma, 1998).

The state most often applies certain methods in combination to achieve the greatest positive effect. First of all, it is necessary to determine for what purposes the procedure of tax stimulation is carried out, and only after the task is solved the introduction and practical application of methods on the procedure of stimulation of the subject of taxation is carried out.

Based on the study of various methods of tax regulation, the following main measures aimed at the development of entrepreneurship are highlighted (Alikaeva \& Ksanaeva, 2013) (Degtyarev, 2009) (Iziev \& Izieva, 2018) (Ksanaeva, 2013):

- reduction of tax rates. Thus, a gradual reduction of tax rates in comparison with the 
generally established ones, first, is used for the stimulation of a certain branch of the economy or is mainly focused on the development of a certain region.

- tax holidays. This method of tax incentives is mainly applied only to newly established organizations and enterprises. Tax holidays allow the subject of taxation not to pay income tax, which certainly provides huge support to the taxpayer for gradual development and strengthening of its position in the Russian economy; - transfer of losses to the future. This measure of tax incentives in most cases is mainly focused on those activities in the process of formation of which, at the initial stage, certain losses are possible. For example, the purchase of high-tech equipment.

- accelerated depreciation. This method of tax incentives allows the subject of taxation to quickly write off a certain value of the capital investment to the cost price in the shortest possible time, rather than if the taxpayer would have used the generally established norms of taxation.

- an investment tax credit. This is the most promising method of tax incentives in the Russian Federation. The main positive result for any organization is its relative "cheapness" in comparison with an ordinary bank loan.

- Withdrawal of certain objects from the taxation procedure (withdrawal). This type is mainly aimed at reducing the tax burden on certain categories of taxes. In this case, the state is denied recognition of transactions in the process of sale, income, as well as the value of the property. This practice is quite widespread, as it is mainly focused on those areas and spheres in which there is interest from the state.

- $\quad$ special tax regimes. At present, the current tax legislation provides for the possibility to apply the following special taxation regimes:

1. the taxation system for agricultural producers.
2. simplified taxation system.

3. the taxation system in the form of a single tax on imputed income for certain types of activities.

4. taxation system when executing production sharing agreements.

5. patent system of taxation.

6. tax on professional income (by experiment) (Duma, 1998) (Duma, 2000).

The above measures regarding the incentive effect are basic, but their list is open, so the state, using the tax policy, achieves the set national goal. The state, which is interested in the progressive, systematic development of the regional economy, should develop such a tax policy, in which the interests of local authorities and business representatives are reflected in the final result, namely, to ensure conditions for the effective progressive development of SMEs.

\section{CONCLUSIONS}

To improve the efficiency of tax regulation of SMEs, in our opinion, it is necessary:

- ensure the formation of an effective policy of tax regulation of the SME sector at the local level.

- increase the limit values of the criteria of revenue and the residual value of fixed assets up to 800 million rubles.

- provide individual entrepreneurs who pay the single tax on total income with the right to use social and property deductions from personal income tax within the limits of the amounts paid tax.

- expand the practice of professional income tax on subjects in the North Caucasus Federal District.

- abolish tax benefits with low or zero efficiency.

- qualitatively implement municipal and private partnership in the sphere of tax regulation of business activity.

\section{WORKS CITED}

Alikaeva, M., \& Ksanaeva, M. (2013). Modernization vector of small business taxation system development. Economics and Entrepreneurship, 3(32), 410-412.

Bykova, N. (2018). Estimation of the state support efficiency for a small business: Cand. of Science: 08.00.05. St. Petersburg. doi:https://disser.spbu.ru/files/2018/disser_bykova_n_v.pdf 
Degtyarev, A. (2009). Tax regulation of the small business development in Russia: Cand. of Sciences: 08.00.10. Moscow. Retrieved from https://www.dissercat.com/content/nalogovoe-regulirovanierazvitiya-malogo-predprinimatelstva-v-rossii

Duma. (1994, 11 30). Part One of the Civil Code of the Russian Federation from 30.11.1994 N 51-FZ. Adopted by the State Duma on 21.10.1994. (in effect, ed.). Retrieved from Information and legal portal "Garant".: https://base.garant.ru/10164072/

Duma. (1998, 12 31). Budget Code of the Russian Federation from 31.12.1998 N 145-FZ. (in effect, ed.). Retrieved from Information and legal portal "Garant": https://base.garant.ru/12112604/

Duma. (1998, 07 31). Part One of the RF Tax Code of 31.07.1998 N 146-FZ. Approved by the State Duma on 16.07.1998. Approved by the Federation Council on 17.07.1998. (in effect, ed.). Retrieved from Information and legal portal "Garant": https://base.garant.ru/10900200/

Duma. (2000, 12 29). Part Two of the Tax Code of the Russian Federation from 29.12.2000 N 166-FZ. Adopted by the State Duma on 19.07.2000. Approved by the Federation Council on 26.07.2000. (in effect, ed.). Retrieved from Information-legal portal "Garant": https://base.garant.ru/10900200/

Duma. (2017, 07 31). Federal law of 24.07.2007 № 209-FZ "On the development of small and medium business in Russia". Rossiyskaya Gazeta - Federal'nyy vypusk(4427). Retrieved from RG.RU: https://rg.ru/2007/07/31/biznes-doc.html

Iskenderova, M. (2018). Tax policy peculiarities in the regulation of small and medium businesses (in Russian). Economics and management: problems, solutions, 1(9), 154-161.

Iziev, K., \& Izieva, L. (2018). State tax regulation of small and medium businesses: measures and guarantees (in Russian). Regional problems of economic transformation, 12(98), 320-326.

Kostromina, E. (2018). Tax regulation of the small business activity in the Russian Federation: problems and prospects of development (in Russian). Scientific community of students: Interdisciplinary research: collection of articles on mat. XLII International Student Scientific-Practical Conf. 7(42), pp. 600-603. Novosibirsk: ANS "SibAK". Retrieved from https://sibac.info/archive/meghdis/7(42).pdf

Ksanaeva, M. (2013). Concept of development of the state support system for small business: on KBR materials: Cand. Vladikavkaz. Retrieved from http://www.dslib.net/economikaxoziajstva/koncepcija-razvitija-sistemy-gosud

Malyshev, E., Belyaev, D., \& Kashurnikova, T. (2018). Tax regulation of the small business at a municipal level (in Russian). Vestnik of Transbaikalian State University, 24(4), 108-118.

Minfin. (2019, 10 03). Osnovnyye napravleniya byudzhetnoy, nalogovoy i tamozhenno-tarifnoy politiki na 2020 god i na planovyy period 2021 i 2022 godov. Retrieved from Minfin Rossii: https://m.minfin.ru/ru/document/?id_38=128344-

osnovnye_napravleniya_byudzhetnoi_nalogovoi_i_tamozhenno-

tarifnoi_politiki_na_2020_god_i_na_planovyi_period_2021_i_2022_godov

Solovyova, O. (2012). Entrepreneurship as the state regulation object (in Russian). Bulletin of Chelyabinsk State University(3 (257)), 19-22.

Zakon. (2018, 11 29). Federal Law "On the Federal Budget for 2019 and the Planned Period of 2020 and 2021" of 29.11.2018 N 459-FZ (last edition). Retrieved from SPS "Consultant Plus": http://www.consultant.ru/document/cons_doc_LAW_312362/ 
Received for publication: $\quad 09.01 .2020$

Revision received: $\quad 23.04 .2020$

Accepted for publication: $\quad 01.07 .2020$

\section{How to cite this article?}

Style - APA Sixth Edition:

Alikaeva, M., Ksanayeva, M., \& Prigoda, L. (2020, July 15). Methodical instruments of state tax regulation of development of small and medium businesses in Russia. (Z. Cekerevac, Ed.) MEST Journal, 8(2), 1-8. doi:10.12709/mest.08.08.02.01

Style - Chicago Sixteenth Edition:

Alikaeva, Madina, Madina Ksanayeva, and Lyudmila Prigoda. 2020. "Methodical instruments of state tax regulation of development of small and medium businesses in Russia." Edited by Zoran Cekerevac. MEST Journal (MESTE) 8 (2): 1-8. doi:10.12709/mest.08.08.02.01.

Style - GOST Name Sort:

Alikaeva Madina, Ksanayeva Madina and Prigoda Lyudmila Methodical instruments of state tax regulation of development of small and medium businesses in Russia [Journal] // MEST Journal / ed. Cekerevac Zoran. - Belgrade - Toronto : MESTE, July 15, 2020. - 2 : Vol. 8. - pp. 1-8.

Style - Harvard Anglia:

Alikaeva, M., Ksanayeva, M. \& Prigoda, L., 2020. Methodical instruments of state tax regulation of development of small and medium businesses in Russia. MEST Journal, 15 July, 8(2), pp. 1-8.

Style - ISO 690 Numerical Reference:

Methodical instruments of state tax regulation of development of small and medium businesses in Russia. Alikaeva, Madina, Ksanayeva, Madina and Prigoda, Lyudmila. [ed.] Zoran Cekerevac. 2, Belgrade - Toronto : MESTE, July 15, 2020, MEST Journal, Vol. 8, pp. 1-8. 